\title{
Influence of Urban Compost on the Yield and Dry Matter of Sesame (Sesamum indicum L.)
}

\author{
K. Avil Kumar ${ }^{1 *}$, K. Sadasiva Rao ${ }^{2}$, M. Uma Devi ${ }^{1}$ and D. Sandeep Kumar ${ }^{1}$
}

${ }^{1}$ Water Technology Centre, ${ }^{2}$ Institute of Agricultural Engineering and Technology, College of Agriculture, Professor Jayashankar Telangana State Agricultural University, Rajendranagar, Hyderabad, India

*Corresponding author

\section{A B S T R A C T}

\section{Keywords}

Inorganic fertilizers,

Urban compost,

Sesame yield,

Harvest index

Article Info

Accepted:

17 November 2019

Available Online:

10 December 2019
The influence of urban compost on yield of sesame is not fully known. In this context, a study was conducted to investigate the effect of varying rates of urban compost in combination with recommended dosage of fertilizers (RDF) on yield of sesame variety, Swetha til. Field experiments were carried out for three years during rabi 2012-2015. The experiments were laid out in randomized block design with three replications. The urban compost was procured from two different dumping yard sources of Hyderabad. One is from Jawahar nagar dumping yard, which was established during 2002 and the second source is Autonagar, which is a more than 50 years old dumping yard. There were eight treatments comprising recommended dose of N,P,K (40:40:20 N, $\mathrm{P}_{2} \mathrm{O}_{5}$ and $\mathrm{K}_{2} \mathrm{O} \mathrm{kg} \mathrm{ha}{ }^{-1}$ ), $\mathrm{RDF}+$ Farm Yard Manure $\left(10 \mathrm{t} \mathrm{ha}^{-1}\right)$, three rates of urban compost from Jawahar nagar $\left(2.5,5\right.$ and $\left.10 \mathrm{t} \mathrm{ha}^{-1}\right)+\mathrm{RDF}$ and three rates of urban compost from Autonagar $(2.5,5$ and $\left.10 \mathrm{t} \cdot \mathrm{ha}^{-1}\right)+\mathrm{RDF}$. Seed yield, stalk yield, total dry matter yield and harvest index were determined. Pooled data analysis results revealed that the beneficial effects of application of urban compost were enhanced up to $5 \mathrm{t} \mathrm{ha}^{-1}$ and then decreased with increasing rates of application. The performance of sesame was superior on the field fertilized with RDF plus $5 \mathrm{t} \mathrm{ha}^{-1}$ urban compost from Jawahar nagar which was comparable to RDF plus $5 \mathrm{t} \mathrm{ha}^{-1}$ urban compost from Autonagar. Application of $5 \mathrm{t} \mathrm{ha}^{-1}$ of urban compost from Jawahar nagar along with RDF recorded highest seed yield (559 kg ha ${ }^{-1}$ ), total dry matter yield $\left(1,909 \mathrm{~kg} \mathrm{ha}^{-1}\right)$ and harvest index $(29.73 \%)$. Thus, the combined use of urban compost and chemical fertilizers may be suitable for improving sesame performance.

\section{Introduction}

Sesame (Sesamum indicum L.) is one of the most important oil seed crops belongs to Pedaliaceae family and extensively grown in different parts of the world and it ranks fourth among oil seed crops in the world. Sesame is drought resistant crop, which can be easily grown under rainfed conditions and it has been grown all over the world for thousands of 
years and said to be ancient crop in India. Sesame is a versatile crop with high quality edible oil having diversified usage. Sesame contains $46-55 \%$ oil, $20-25 \%$ protein also contains vitamins, amino acids and polyunsaturated fatty acids. Sesame can play an important role to fulfill the local demand of edible oil. As sesame is short duration and photo insensitive crop with wider adaptability, it can be cultivated throughout the year. Considering the low yield of sesame obtained in most growing areas as a result of poor fertility status of soils, there is the need to assess the performance of sesame using different organic manure. Integrated use of organic manure and chemical fertilizer would be quite promising not only in providing greater stability in production, but also in maintaining better soil fertility (Nambiar, 1991). Thus, it is necessary to find out site specific integrated use of nutrients from organic and inorganic sources for sustainable crop production.

With the development of modern societies in which raw consumerism and the culture of "throwaway" is on the agenda, the problem of urban solid waste is becoming ever greater. Land filling disposal of wastes contributes flooding, breeding of insect and rodent vectors, the spread of diseases and polluting ground water quality. Using a good strategy such as composting process, solid wastes can be converted into useful products for improvement of soils properties (Hashemimajd et al., 2004; Sohrabi Yourtchi et al., 2013). Urban compost can be considered as a valuable source of nitrogen $(\mathrm{N})$, phosphorous (P), essential trace elements, and organic matter that will improves soil physical properties and plant nutritional status (Bertoldi et al., 1996; Zinati et al., 2004; Kabirinejad and Hoodaji 2012). Furthermore, use of urban compost can reduce the agricultural demands for water, fertilizers and pesticides (Hoitink et al., 1997; Weltzien, 1989; Sahin and Bolukbasi, 2009). Composting also extends the life of the municipal landfill by diverting organic materials from landfills to agricultural lands. Albert Ribas-Agustí et al., (2016) studied the effect of fertilizing with compost obtained from the organic fraction of MSW, on crop yield, crop quality and phenolic content of tomato fruit. Compared with the use of mineral fertilizer (M), fertilization with MSW compost alone (C) or combined with mineral fertilizer $(\mathrm{C}+\mathrm{M})$ had no significant effect on tomato fruit quality characterized by weight, diameter or Brix, nor was there a significant effect on total phenolic content. In contrast, the $\mathrm{C}$ treatment altered the phenolic profile by enhancing a kaempferol derivative, and caused a 43 and $48 \%$ yield reduction compared with the $\mathrm{C}+\mathrm{M}$ and $\mathrm{M}$ treatments, respectively. Overall, composted MSW + mineral fertilizer appeared to be the best strategy for the reutilization of MSW in tomato culture, as it did not compromise crop yield or fruit quality. Youssef Ouni et al., (2014) investigated the response of $H$. vulgare and $P$. monspeliensis to different doses (0, 100 , and $150 \mathrm{t} \mathrm{ha}^{-1}$ ) of municipal solid waste (MSW) compost in a greenhouse pot experiment. Results showed that compost supply significantly increased shoot and root dry weights of both species, and this was positively correlated with nutrient uptake. Chlorophyll and carotenoid contents were positively influenced, especially in $H$. vulgare at rate of $100 \mathrm{t} \mathrm{ha}^{-1}$. Furthermore, MSW compost application increased net photosynthetic rate (A), stomatal conductance (Gs), and water-use efficiency (WUE) in both species. Alternatively, MSW compost amendment increased plant heavy-metal contents but levels remained lower than phytotoxic thresholds. This preliminary study suggests that a MSW supply at moderate doses (100 t ha ${ }^{-1}$ ) could be highly beneficial for plant productivity on saline soils. However, there is inadequate information on 
the use and effect of urban compost on nutrient uptake and yield of sesame. Therefore, a study was conducted to assess the effect of urban compost on yield of sesame.

\section{Materials and Methods}

Field experiments were conducted at College farm, PJTSAU, Rajendranagar to investigate the effect of urban compost in combination with inorganic fertilizers on the yield of sesame during rabi 2012-2015. Experiment was laid out in a randomized block design (RBD) with three replications. Sesame variety Swetha til was used for the study. Each plot measured $5.1 \mathrm{~m} \mathrm{x} 3.9 \mathrm{~m}$ with $30 \mathrm{~cm}$ row to row and $10 \mathrm{~cm}$ plant to plant distance. The different treatments consists of; Urban Compost - I \& II @ 2.5, 5.0 \& $10.0 \mathrm{t} \mathrm{ha}^{-1}$ and Farm Yard Manure $\left(10 \mathrm{t} \mathrm{ha}^{-1}\right)$ in addition to recommended dose of N,P,K (RDF, 40:40:20 $\mathrm{N}, \mathrm{P}_{2} \mathrm{O}_{5}$ and $\mathrm{K}_{2} \mathrm{O} \mathrm{kg} \mathrm{ha}{ }^{-1}$ ) as detailed in table 1.

The urban compost was procured from two different dumping yard of Hyderabad. One from Jawahar nagar (Urban Compost - I) where urban waste is managed in a scientific way by segregating the different materials, recycling of non bio degradable waste materials (plastic, metals etc) and composting bio degradable waste.

Other from Autonagar (Urban Compost -II) which is a more than 50 years old dumping yard, where urban waste was just dumped without segregating bio degradable and non bio degradable waste material.

The compost was formed naturally over a period of time. The compost from this place was collected just by screening. The compost from both the sources were applied at three different rates along with recommended dose of fertilizers as per treatments. All other agronomic practices were kept uniform to keep the crop free from pests. At maturity seed yield, stalk yield, total dry matter yield and harvest index were measured. Data pertaining to these parameters was tabulated and subjected to statistical analysis for interpretation of results.

\section{Results and Discussion}

\section{Seed yield $\left(\mathrm{kg} \mathrm{ha}^{-1}\right)$}

Analysis of data showed that the yield of sesame was significantly affected by urban compost in combination with inorganic fertilizers (Table 1). The crop applied with urban compost from Jawaharnagar (Urban Compost -I) @ 5.0 t ha ${ }^{-1}$ along with RDF of 40:40:20 N, $\mathrm{P}_{2} \mathrm{O}_{5}$ and $\mathrm{K}_{2} \mathrm{O} \mathrm{kg} \mathrm{ha}{ }^{-1}$ recorded significantly higher seed yield of $559 \mathrm{~kg} \mathrm{ha}^{-1}$ followed by the crop applied with urban compost from Autonagar (Urban Compost -II) @ $5.0 \mathrm{t} \mathrm{ha}^{-1}$ along with RDF and significantly superior over rest of the treatments.

Significantly lower yield of $410 \mathrm{~kg} \mathrm{ha}^{-1}$ was recorded with crop applied with RDF of 40:40:20 N, $\mathrm{P}_{2} \mathrm{O}_{5}$ and $\mathrm{K}_{2} \mathrm{O} \mathrm{kg} \mathrm{ha}{ }^{-1}$ and was on par with application of FYM $5.0 \mathrm{t} \mathrm{ha}^{-1}$ and urban compost of both sources@ $2.5 \mathrm{t} \mathrm{ha}^{-1}$. This could be attributed to the ability of urban compost to supply nutrients contained in them gradually to support crop growth which later translated to high yield (Aliyu, 2003 and Anon., 2007) (Fig. 1).

\section{Stalk yield $\left(\mathrm{kg} \mathrm{ha}^{-1}\right)$}

The maximum stalk yield of $1,367 \mathrm{~kg} \mathrm{ha}^{-1}$ was recorded in $T_{3}$ viz., urban compost from Jawaharnagar (Urban Compost -I) @ 2.5 $\mathrm{t} \mathrm{ha}^{-1}$ along with RDF of 40:40:20 N, $\mathrm{P}_{2} \mathrm{O}_{5}$ and $\mathrm{K}_{2} \mathrm{O} \mathrm{kg} \mathrm{ha}{ }^{-1}$ and were on par with the urban compost from Autonagar (Urban Compost -II) @ $5.0 \mathrm{t} \mathrm{ha}^{-1}+\mathrm{RDF}$ (Table 1). The lowest stalk yield of $1,231 \mathrm{~kg} \mathrm{ha}^{-1}$ was recorded in the treatment $\mathrm{T}_{8}$ viz., urban compost from 
Autonagar (Urban Compost -I) @ $10 \mathrm{t} \mathrm{ha}^{-1}$ along with RDF.

Total dry matter yield $\left(\mathrm{kg} \mathrm{ha}^{-1}\right)$

Maximum total dry matter yield $(1,909 \mathrm{~kg}$ $\mathrm{ha}^{-1}$ ) was recorded in $\mathrm{T}_{4}$ (Urban Compost-I @ $\left.5.0 \mathrm{tha}^{-1}+\mathrm{RDF}\right)$ which was statistically at par with $\mathrm{T}_{7}$ (Urban Compost-II @ $5.0 \mathrm{t} \mathrm{ha}^{-1}+$ RDF). Significantly lowest total dry matter yield $\left(1,659 \mathrm{~kg} \mathrm{ha}^{-1}\right)$ was obtained from $\mathrm{T}_{1}$ (RDF).

Table.1 Effect of urban compost on seed, stalk yield, total dry matter production and harvest index of sesame (Swetha - til) during rabi, 2012-15

\begin{tabular}{|c|c|c|c|c|c|c|c|c|}
\hline \multirow{2}{*}{ Treatments } & \multicolumn{4}{|c|}{ Seed yield $\left(\mathrm{kg} \mathrm{ha}^{-1}\right)$} & \multicolumn{4}{|c|}{ Stalk yield $\left(\mathrm{kg} \mathrm{ha}^{-1}\right)$} \\
\hline & $\begin{array}{c}2012- \\
13\end{array}$ & $\begin{array}{c}2013- \\
14\end{array}$ & $\begin{array}{c}2014- \\
15\end{array}$ & Mean & $\begin{array}{c}2012- \\
13\end{array}$ & $\begin{array}{c}2013- \\
14\end{array}$ & $\begin{array}{c}2014- \\
15\end{array}$ & Mean \\
\hline T1-RDF & 424 & 408 & 400 & 411 & 1531 & 1091 & 1123 & 1248 \\
\hline T2-FYM $\left(10.0 \mathrm{t} \mathrm{ha}^{-1}\right)$ & 488 & 438 & 376 & 434 & 1680 & 1189 & 1139 & 1336 \\
\hline T3-UC-I $\left(2.5 \mathrm{t} \mathrm{ha}^{-1}\right)$ & 537 & 435 & 354 & 442 & 1856 & 1217 & 1029 & 1367 \\
\hline T4-UC-I $\left(5.0 \mathrm{t} \mathrm{ha}^{-1}\right)$ & 661 & 564 & 453 & 559 & 1775 & 1290 & 985 & 1350 \\
\hline T5-UC-I (10.0 t ha- & 523 & 435 & 435 & 464 & 1653 & 1247 & 1136 & 1345 \\
\hline T6-UC-II $\left(2.5 \mathrm{t} \mathrm{ha}^{-1}\right)$ & 523 & 459 & 406 & 463 & 1558 & 1140 & 1025 & 1241 \\
\hline T7-UC-II $\left(5.0 \mathrm{t} \mathrm{ha}^{-1}\right)$ & 615 & 545 & 415 & 525 & 1762 & 1313 & 1003 & 1359 \\
\hline T8-UC-II $\left(10.0 \mathrm{t} \mathrm{ha}^{-1}\right)$ & 515 & 474 & 403 & 464 & 1518 & 1243 & 933 & 1231 \\
\hline S.Em \pm & 33 & 23 & 18 & 17 & 98 & 41 & 42 & 42 \\
\hline C.D. $(P=0.05)$ & 100 & 70 & 55 & 52 & 298 & 126 & 127 & NS \\
\hline
\end{tabular}

\begin{tabular}{|c|c|c|c|c|c|c|c|c|}
\hline \multirow[t]{2}{*}{ Treatments } & \multicolumn{4}{|c|}{ Total dry matter yield $\left(\mathrm{kg} \mathrm{ha}^{-1}\right)$} & \multicolumn{4}{|c|}{ Harvest index yield (\%) } \\
\hline & $\begin{array}{c}2012- \\
13\end{array}$ & $\begin{array}{c}2013- \\
14\end{array}$ & $\begin{array}{c}2014- \\
15\end{array}$ & Mean & $\begin{array}{c}2012- \\
13\end{array}$ & $\begin{array}{c}2013- \\
14\end{array}$ & $\begin{array}{c}2014- \\
15\end{array}$ & Mean \\
\hline T1-RDF & 1955 & 1499 & 1523 & 1659 & 21.7 & 27.3 & 26.4 & 25.1 \\
\hline T2-FYM $\left(10.0 \mathrm{t} \mathrm{ha}^{-1}\right)$ & 2168 & 1626 & 1515 & 1770 & 22.6 & 27.0 & 24.8 & 24.8 \\
\hline T3-UC-I $\left(2.5 \mathrm{t} \mathrm{ha}^{-1}\right)$ & 2393 & 1652 & 1382 & 1809 & 22.5 & 26.3 & 25.6 & 24.8 \\
\hline T4-UC-I $\left(5.0 \mathrm{t} \mathrm{ha}^{-1}\right)$ & 2436 & 1854 & 1438 & 1909 & 27.3 & 30.4 & 31.5 & 29.7 \\
\hline T5-UC-I $\left(10.0 \mathrm{t} \mathrm{ha}^{-1}\right)$ & 2176 & 1682 & 1571 & 1810 & 24.0 & 25.8 & 27.7 & 25.8 \\
\hline T6-UC-II $\left(2.5 \mathrm{t} \mathrm{ha}^{-1}\right)$ & 2081 & 1599 & 1431 & 1704 & 25.2 & 28.7 & 28.4 & 27.4 \\
\hline T7-UC-II $\left(5.0 \mathrm{t} \mathrm{ha}^{-1}\right)$ & 2377 & 1857 & 1418 & 1884 & 26.2 & 29.3 & 29.3 & 28.3 \\
\hline T8-UC-II (10.0 t ha' & 2033 & 1717 & 1336 & 1695 & 25.4 & 27.5 & 30.1 & 27.7 \\
\hline S.Em \pm & 86 & 49 & 41 & 37 & 1.8 & 1.2 & 1.3 & 1.4 \\
\hline C.D. $(P=0.05)$ & 262 & 147 & 125 & 114 & NS & NS & 4.0 & NS \\
\hline
\end{tabular}

* U.C. I = Urban compost from Jawahar Nagar, Hyderabad, U.C. II = Urban compost from Autonagar, Hyderabad. A common recommend dose of 40:40:20 kg N-P $\mathrm{P}_{2} \mathrm{O}_{5}-\mathrm{K}_{2} \mathrm{O}$ was applied to all the treatments. 


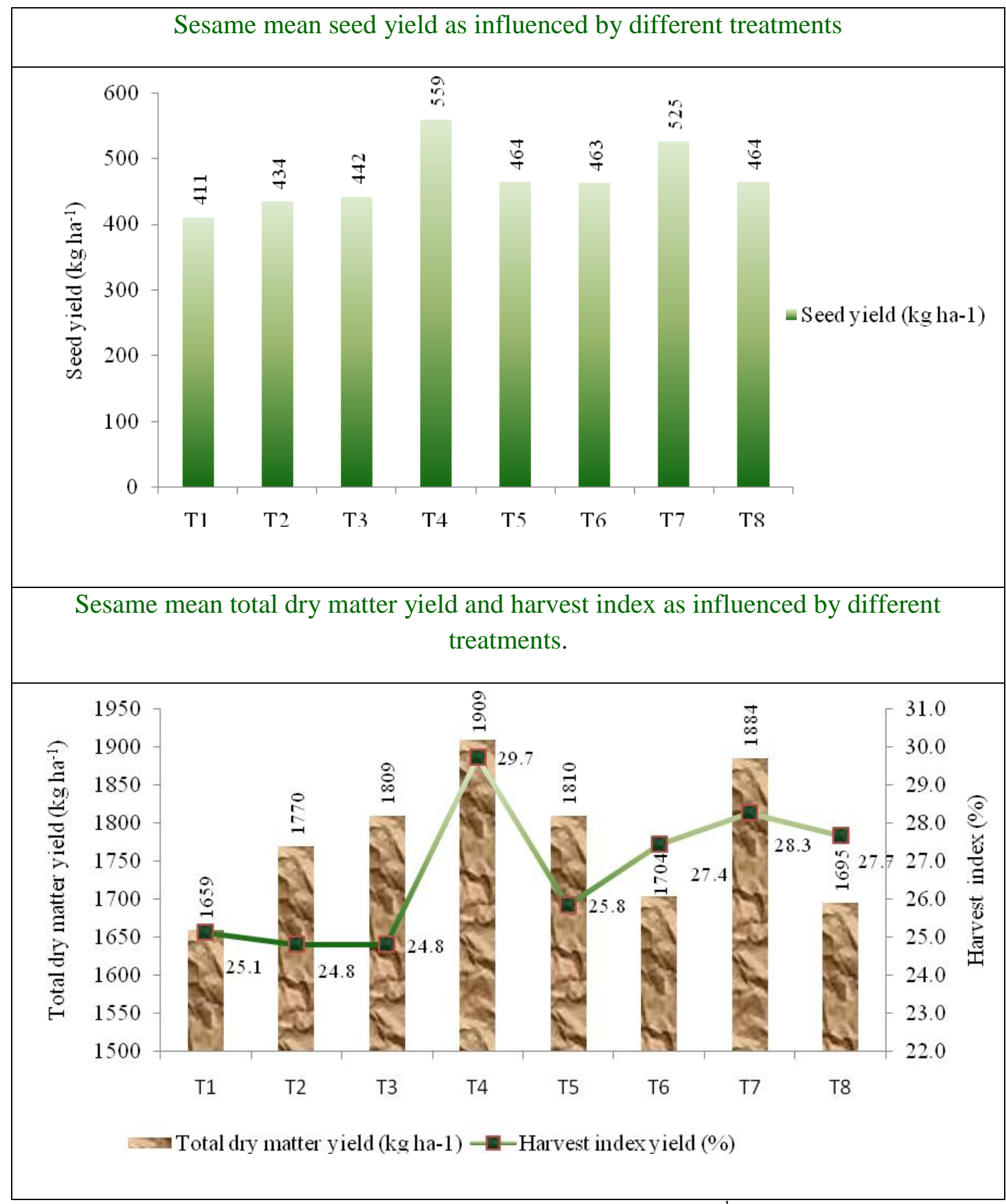

T1- Recommended dose of N,P,K ( RDF), T2-RDF+ Farm Yard Manure ( $\left.10 \mathrm{t} \mathrm{ha}^{-1}\right)$, T3- RDF + Urban Compost - I $\left(2.5 \mathrm{t} \mathrm{ha}^{-1}\right), \mathrm{T} 4-\mathrm{RDF}+\mathrm{Urban}$ Compost $-\mathrm{I}\left(5.0 \mathrm{t} \mathrm{ha}^{-1}\right), \mathrm{T} 5-\mathrm{RDF}+\mathrm{Urban}$ Compost $-\mathrm{I}\left(10.0 \mathrm{t} \mathrm{ha}^{-1}\right), \mathrm{T} 6-\mathrm{RDF}+\mathrm{Urban}$ Compost -II $\left(2.5 \mathrm{t} \mathrm{ha}^{-1}\right), \mathrm{T} 7-\mathrm{RDF}+$ Urban Compost -II $\left(5.0 \mathrm{t} \mathrm{ha}^{-1}\right)$ and T8- RDF + Urban Compost -II (10.0 $\left.\mathrm{t} \mathrm{ha}^{-1}\right)$.

Higher total dry matter yield might be due to the increase in growth and yield attributes. Plant growth biomass is the indicator of good uptake of nutrients from the soil.
When organic manure was applied with inorganic fertilizer more nutrient uptake happened in the plant system and so more plant biomass was recorded. Kelling et 
al., (1977) and Voagtmann and Fricke (1989) also have found that compost application had the stimulation effect on sesame shoots and roots dry weight at different growth stages.

\section{Harvest index (\%)}

Urban compost from Jawaharnagar (Urban Compost -I) applied at the rate of $5.0 \mathrm{t} \mathrm{ha}^{-1}$ along with RDF recorded maximum harvest index $(29.7 \%)$, followed by $5 \mathrm{t} \mathrm{ha}^{-1}$ of urban compost from Autonagar (28.3\%).

The minimum harvest index $(24.8 \%)$ was recorded from plots applied with urban compost from Jawaharnagar (Urban Compost -I) @ $2.5 \mathrm{t} \mathrm{ha}^{-1}$ along with RDF and RDF+ Farm Yard Manure @ 10 t ha ${ }^{-1}$. The physiological efficiency of crop plants in converting photosynthetic products into grain yield is termed as harvest index (Khaliq et al., 2004). Higher harvest index was recorded from urban compost incremental levels up to 5 $\mathrm{t} \mathrm{ha}^{-1}$. This increased harvest index could be associated with enhanced soil cation exchange capacity, increased $\mathrm{C}, \mathrm{N}$, and $\mathrm{P}$ content, and lowered hydraulic conductivity of soil, That might had improved photosynthetic efficiency (Liu et al., 2004) and enhanced assimilates translocation to economic portion (Smaling et al., 2002) which all have direct effects on seed yield, that might have resulted in higher harvest index.

From the results of the present investigation, it could be concluded that urban compost can be used successfully in increasing crop productivity along with inorganic fertilizers. The introduction of urban compost is beneficial in the successful production of sesame. Among different levels of urban compost, application of urban compost @ $5 \mathrm{t}$ $\mathrm{ha}^{-1}$ along with RDF was found ideal for sesame in order to obtain higher seed yield.

\section{References}

Albert Ribas-Agustí., Marta Seda., Carmen Sarraga and Juan I. Montero. 2017. Municipal solid waste composting: Application as a tomato fertilizer and its effect on crop yield, fruit quality and phenolic content. Renewable Agriculture and Food Systems. 32(4): 358-365.

Aliyu, L. (2003). Effect of nitrogen and phosphorus on the chemical composition and Uptake of mineral elements by pepper (Capsicum annum L.). Crop Research, 25(2), 272-279.

Bertoldi, M., Sequi, P., Lemmens B, Papi T (eds) (1996) The science of composting, Part 1, 1st edn. Blakie Academic and Professional, Glasgow.

Hashemimajd, K., Kalbasi, M., Golchin, A and Shariatmadari, H. 2004. Comparison of vermi compost and composts as potting media for growth of tomatoes. J Plant Nutr. 27(6): 1107-1123.

Hoitink, H.A.J., Stone, A.G and Han, D.Y. 1997. Suppression of plant diseases by composts. Hort Science, 32: 184-187.

Kabirinejad, S., Hoodaji, M. 2012. The effects of biosolid application on soil chemical properties and Zea mays nutrition. Int J Recycl Organic Waste Agric. 1: 4.

Kelling, K.A., Peterson, A.E., Walsh, L.M., Ryan, J.A and Keeny, D.R. 1977. A field study of the agricultural use of sewage sludge: I. Effect on crop yield and uptake of $\mathrm{N}$ and P. J. Environ. Qual., 6: 339-345.

Khaliq, T., Mahmood, T., Kamal, J., Masood, A. 2004. Effectiveness of farmyard manure, poultry manure and nitrogen for corn (Zea mays L.) productivity. Int J Agri Biol 6: 60-63.

Liu, X., Herbert, S.J., Jin, J., Zhang, Q., Wang, G. 2004. Responses of 
photosynthetic rates and yield/quality of main crops to irrigation and manure application in the black soil area of Northeast Chin. Plant and Soil 261: 55-60.

Nambiar, K.K.M. 1991. Long term fertility effects on wheat productivity. Proc. Int. Conf. Maxico. DF. CIMMYT: 516-560.

Sahin, S and Bolukbasi, A. 2009. The effect on organic agriculture of insulation of rural houses in Turkey. Asian J. Applied Sci., 2: 394-401.

Smaling, E.M.A., Nandwa, S.M., Prestle, H., Roetter, H and Muchena, F.N. 2002. Yield response of maize to fertilizers and manure under different agroecological conditions in Kenya, Elsevier Dordrecht, Netherlands. 41: 241-252.

Sohrabi Yourtchi, M., Haj Seyyed Hadi, M.R and Darzi, M.T. 2013. Effect of nitrogen fertilizer and vermi compost on vegetative growth, yield and NPK uptake by tuber of potato (Agria CV.).
Int J Agric Crop Sci. 5(18): 20332040.

Voagtmann, H. and Fricke, K. 1989. Nutrient value and utilization of biogenic compost in plant production. Agric. Ecosyst. Environ., 27: 471-475.

Weltzien, H.C. 1989. Some effects of composted organic materials on plant health. Agric. Ecosyst. Environ., 27: 439-446.

Youssef Ouni., Enrique Mateos-Naranjo., Abdelbasset Lakhdar., Luis AndradesMoreno., Chedly Abdelly and Zouhaeir Barhoumi. 2014. Municipal solid waste compost application improves the negative impact of saline soil in two forage species. 45(10).

Zinati, G.M., Li, Y.C., Bryan, H.H., Mylavarapu, R.S and Cadallo M. 2004. Distribution and fractionation of phosphorus, cadmium, nickel, and lead in calcareous soils amended with composts. J Environ Sci Health B. 39(1): 209-223.

\section{How to cite this article:}

Avil Kumar, K., K. Sadasiva Rao, M. Uma Devi and Sandeep Kumar, D. 2019. Influence of Urban Compost on the Yield and Dry Matter of Sesame (Sesamum indicum L.). Int.J.Curr.Microbiol.App.Sci. 8(12): 2317-2323. doi: https://doi.org/10.20546/ijcmas.2019.812.273 